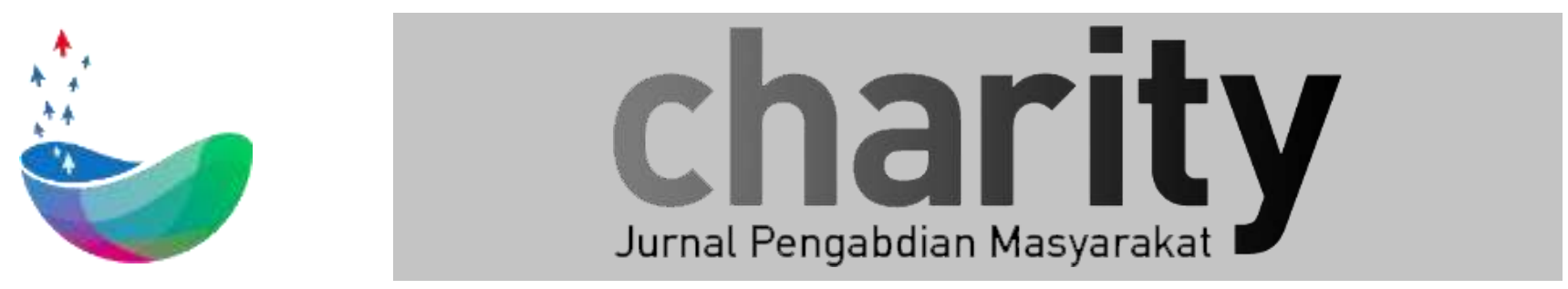

\title{
PENGABDIAN KEPADA MASYARKAT PELATIHAN PEMANFAATAN RUMAH PINTAR OLEH MASYARAKAT DALAM RANGKA MENGURANGI KESENJANGAN DIGITAL DESA WARGA SALUYU 2017
}

\author{
Mellia Liyanthy ${ }^{1}$, Anggoro Ari Nurcahyo ${ }^{2}$, R. Djunaedy Sakam ${ }^{3}$
}

${ }^{1}$ Universitas Pasundan Bandung

${ }^{2}$ Universitas Pasundan Bandung

${ }^{3}$ Universitas Pasundan Bandung

*liyanthy@unpas.ac.id

\section{INFO ARTIKEL}

Diterima 2 November 2017

Direvisi 7 November 2017

Disetujui 16 November 2017

Tersedia Online 24 Oktober 2018

\begin{abstract}
ABSTRAK
Kesenjangan digital yang terjadi di Indonesia disebabkan oleh pembangunan infrastruktur Information Communication Technology (ICT) yang belum merata, pembangunan rumah pintar di pedesaan merupakan salah satu upaya untuk mengatasi hal tersebut. Tapi hal tersebut bukan satu- satunya penyebab, karena dapat juga disebabkan oleh ketidaksiapan masyarakat untuk memanfaatkan infratruktur ICT tersebut. Oleh karena itu dibutuhkan sebuah upaya untuk mempersiapkan masyarakat agar pemanfaatannya menjadi optimal. Pelatihan merupakan salah satu upaya yang bisa dilakukan untuk mengatasi permasalahan tersebut. Tahapan pelatihan meliputi identifikasi kebutuhan, perencanaan, pelaksanaan dan evaluasi. Terdapat 4 indikator yang digunakan untuk mengukur tingkat kesiapan masyarakat yaitu reaksi, pembelajaran, perilaku kerja, dan hasil. Pelatihan yang telah dilakukan mendapatkan tanggapan yang positif lebih dari $90 \%$ peserta, yang menyatakan sudah mengetahui dan termotivasi untuk memanfaatkan rumah pintar dalam pekerjaan mereka sehari-hari, maka dengan demikian dapat membantu mengurangi kesenjangan digital yang masih terjadi saat ini.
\end{abstract}

Keyword : kesenjangan digital, pelatihan rumah pintar, ICT

Korespondensi :

Direktorat Penelitian dan Pengabdian Masyarakat, Universitas Telkom

Jl. Telekomunikasi No. 1, Terusan Buah Batu, Bandung, 40257

Indonesia.

E-mail: charity@telkomuniversity.ac.id

ORCID ID:

Penulis Pertama: -

https://doi.org/10.25124/charity.v1i01.1587

Paper_reg_number Charity0014010114 (C) The Authors. Published by Directorate of Research and Community Service, Telkom University.

This is an open access article under the CC BY-NC license (https://creativecommons.org/licenses/by-nc/4.0/) 


\section{RUMUSAN MASALAH}

Information Communication Technology (ICT) sudah semakin banyak digunakan dalam berbagai kegiatan manusia sehari-hari karena kemudahan yang ditawarkan. Tetapi pemanfaatan ICT tersebut belum merata di Indonesia, sehingga masih terdapat kesenjangan digital terutama antara masyarakat perkotaan dengan pedesaan. Hal ini disebabkan karena ketersedian infrastruktur yang belum merata. Ternyata infrakstruktur bukan merupakan satusatunya permasalahan kesenjangan digital ini, karena sudah banyak upaya untuk membangun infrastruktur yang sering disebut dengan rumah pintar, tapi upaya tersebut belum dapat mengurangi kesenjangan digital tersebut, hal ini dikarenakan ketidaksiapan masyarakat untuk menggunakan infrastruktur tersebut, baik dari sisi pengetahuan maupun dari sisi motivasi, sehingga infrastruktur tersebut tidak dapat dimanfaatkan secara optimal oleh masyarakat. Oleh karena itu pada kegiatan pengabdian masyarakat ini akan dilakukan upaya untuk mempersiapkan masyarakat dalam memanfaatkan infrastruktur ICT. 
Desa warga saluyu merupakan desa binaan dari Fakultas Teknik Universitas Pasundan, dimana desa ini masih dikategorikan sebagai desa tertinggal, salah satunya karena minimnya pemanfaatan teknologi dalam pekerjaan mereka sehari-hari, sehingga hal tersebut menjadikan masyarakat desa tersebut tidak mampu bersaing dengan desa lainnya. Sudah cukup banyak masyarakat yang menggunkan handphone tapi belum bisa mengoptimalkan penggunaannya.

Akses internet masih sangat terbatas, tingkat pendidikan masyarakat masih relatif rendah sehingga sulit untuk memperoleh informasi dari luar secara cepat. Oleh karena ini dalam kegiatan pengabdian masyarakat yang akan dilakukan oleh Program Studi Teknik Informatika Universitas Pasundan akan mendirikan rumah pintar dan khusus dalam makalah ini akan membahas mengenai upaya untuk mempersiapkan masyarakat agar dapat memanfaatkan rumah pintar tersebut secara optimal, sehingga diharapkan dapat mengurangi kesenjangan digital di lingkungan Desa Warga Saluyu.

\section{METODE PELAKSANAAN PENGABDIAN MASYARAKAT}

1. Metode

Pelaksanaan pemanfaatan Rumah Pintar untuk mengakses informasi dilakukan dengan cara pelatihan. Tahapan penyelenggaraan pelatihan tersebut adalah sebagai berikut: (Icmi 2015)

a. Identifikasi Kebutuhan Pelatihan

Terdapat 3 tingkatan analisis untuk mengidentifikasi kebutuhan pelatihan yang meliputi: (Schuler \& Huber, 1993)

1) Analisis Organisasi bertujuan untuk mengenali organisasi tempat penyelenggaraan pelatihan, sehingga dapat diketahui siapa dan dimana pelatihan akan diselenggarakan.

2) Analisis operasi bertujuan untuk mengetahui materi apa saja yang diperlukan dalam pelatihan yang akan diselenggarakan.

3) Analisis individual bertujuan untuk mengetahui kemampuan, pengetahuan dan karakteristik dari peserta pelatihan.

b. Perencanaan

Perencanaan dilakukan berdasarkan kebutuhan pelatihan yang telah teridentifikasi pada tahap sebelumnya. Tujuan dari perencanaan adalah untuk menentukan secara sistematis tahapan kegiatan diklat, sehingga hal-hal yang perlu ditentukan dalam tahapan perencanaan adalah: 
1) Tujuan pelatihan, sehingga dapat diketahui luaran dari pelatihan yang akan dilakukan tersebut.

2) Materi pelatihan yang sesuai dengan kebutuhan pelatihan, sehingga tujuan dari pelatihan bisa tercapai.

3) Model pelatihan yang tepat untuk digunakan pada proses pembelajaran, sesuai dengan materi pelatihan yang telah ditetapkan, untuk mendukung ketercapaian tujuan dari pelatihan. Model pelatihan yang akan digunakan adalah instructor-led (Arahan Instruktur) merupakan metode pelatihan yang efektif, karena indtruktur dapat menyampaikan sejumlah besar informasi dalam waktu yang relatif singkat. (Dessler, 2008)

4) Alat evaluasi yang akan digunakan untuk mengukur tingkat ketercapaian tujuan dari pelatihan. Alat evaluasi yang akan digunakan adalah kuisioner (angket), dan pengamatan oleh fasilitator yang menyampaikan materi pelatihan.

c. Pelaksanaan

Pelaksanaan pelatihan terdiri dari tahapan-tahapan sebagai berikut:

1) Pembukaan yang menendakan dimulainya kegiatan pelaksanaan pelatihan. Hal yang dipersiapkan pada tahap ini meliputi: pejabat yang akan memberikan arahan dan membuka kegiatan pelatihan, personil yang diperlukan dalam pembukaan acara, laporan acara pembukaan, tempat dan perlengkapan pendukung, serta menyiapkan lingkungan psikologis yang menyenangkan bagi peserta.

2) Pelaksanaan proses pelatihan merupakan proses pembelajaran yang terjadi antara fasilitator dengan peserta pelatihan. Hal yang dipersiapkan pada tahap ini meliputi: daftar kehadiran peserta, sarana dan prasarana, kesiapan fasilitator. Tahapan ini harus dipersiapkan secara baik agar pelatihan yang dilakukan dapat mencapai tujuannya.

3) Penutupan yang menandakan kegiatan pelatihan telah selesai dilaksanakan. Hal yang harus dipersiapkan hampir sama dengan pembukaan. Penutupan yangmeriah akan memberikan kesan yang mendalam bagi diri peserta.

d. Evaluasi

Evaluasi merupakan tahapan terakhir dalam penyelenggaraan pelatihan untuk mengetahui tingkat keberhasilan dari pelatihan dalam mencapai tujuannya. Evaluasi akan difokuskan pada tahap pelaksanaan proses pembelajaran. Tahapan evaluasi terdiri dari: 
1) Pengukuran akan dilakukan dengan menggunakan kuesioner yang akan diisi oleh peserta pelatihan

2) Penilaian dilakukan terhadap data hasil pengukuran yang telah dilakukan sebelumnya.

3) Kesimpulan dan Saran

Alur dari metode pelaksanaan pelatihan pemanfaatan Rumah Pintar oleh masyarakat dapat dilihat pada gambar 1.

\section{Identifikasi Kebutuhan}
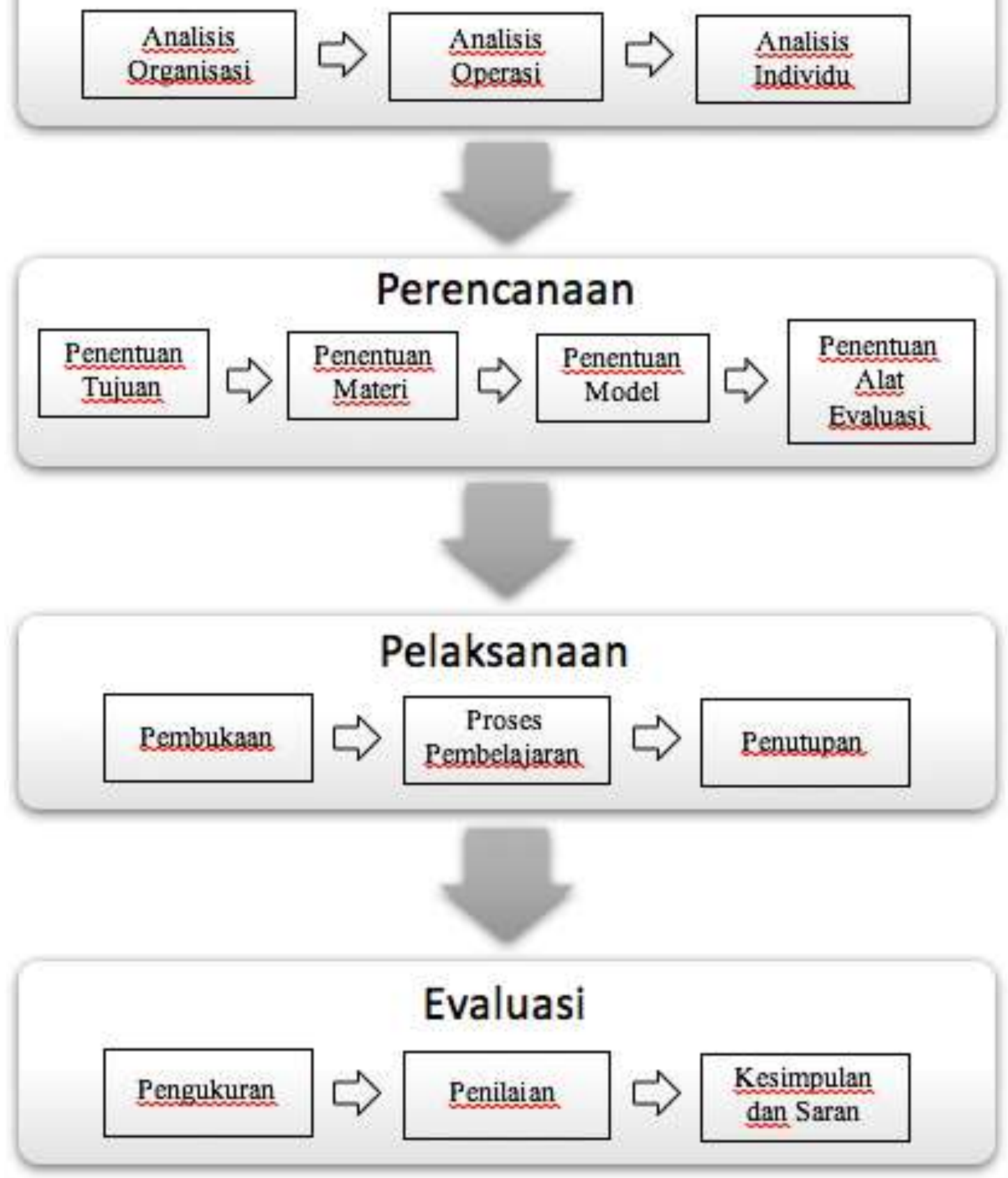

Gambar 1 Metode Pelatihan 
2. Teknik Pengumpulan Data Pengumpulan data yang dilakukan dalam kegiatan pengabdian pada masyarakat ini terdiri dari tiga cara, yaitu: (Icmi, 2015)

a. Wawancara dilakukan untuk mengumpulkan data sehingga dapat diketahui kebutuhan pelatihan apa yang diperlukan oleh masyarakat agar dapat memanfaatkan rumah pintar dan untuk mengetahui timbal balik dari peserta pelatihan setelah kegiatan pelatihan selesai dilaksanakan. Wawancara dilakukan oleh fasilitator terhadap masyarakat yang akan menjadi peserta pelatihan. Wawancara dilakukan dengan dua cara yaitu lisan dan tulisan yang didokumentasikan berupa kuesioner, yang dilakukan dua kali yaitu sebelum dan sesudah kegiatan pelatihan diselenggarakan.

b. Observasi dilakukan untuk mengamati efektifitas dari kegiatan pelatihan yang diselenggarakan agar dapat mencapai tujuan dari pelatihan tersebut. Observasi dilakukan oleh fasilitator terhadap hasil pelatihan dan didokumentasikan dalam bentuk berita acara kegiatan.

c. Dokumentasi adalah teknik pengumplan data melalui dokumen-dokumen yang digunakan dalam pelatihan tersebut. Teknik pengumpulan data ini diperlukan untuk menyimpulkan hasil dari kegiatan pelatihan yang telah dilakukan.

3. Teknik Analisa Data

Teknik analisis data yang digunakan dalam kegiatan pengabdian masyarakat ini adalah teknik analisi kualitatif dengan metode deskriptif. Aktivitas dalam teknik analisis data ini meliputi: (Icmi, 2015)

a. Reduksi data yaitu memilah-milah data sehingga dapat diperoleh data-data pokok dan penting untuk mendukung kegiatan pelatihan yang akan dan telah diselenggarakan, serta mengabaikan data-data yang tidak diperlukan.

b. Penyajian data dilakukan dengan uraian singkat, bagan atau diagram, sehingga data yang diperoleh dapat lebih mudah dipahami.

c. Penarikan kesimpulan dilakukan dengan cara menyusun pola hubungan antar data sehingga dapat ditafsirkan dengan mudah untuk selanjutnya dibuat kedimpulan berdasarkan pola hubungan antar data tersebut.

4. Lokasi, Waktu dan Durasi Kegiatan

Kegiatan pelatihan diselenggarakan di Desa Warga Saluyu, Kecamatan Gunung Halu, Kabupaten Bandung Barat, pada bulan April 2017 sampai dengan bulan Agustus 2017, yang dilakukan satu kali setiap bulannya, selama 2 jam untuk setiap kelompok peserta pelatihan. 


\section{ANALISA HASIL KEGIATAN PENGABDIAN MASYARAKAT}

1. Luaran atau Fokus Utama Kegiatan Terdapat dua luaran atau focus utama dari kegiatan pelatihan pemanfaatan rumah pintar yang telah dilakukan, yaitu:

a. Modul pelatihan yang sesuai dengan tujuan penyelenggaraan pelatihan. Berdasarkan hasil wawancara yang dilakukan sebelum pelaksanaan pelatihan, diperoleh fakta bahwa sebagian besar masyarakat masih awam dengan aplikasi-aplikasi komputer dan perolehan informasi yang mereka perlukan untuk penunjang pekerjaan mereka masih dilakukan secara konvensional, maka modul pelatihan yang dibutuhkan adalah sebagai berikut:

1) Pengenalan internet, website, web browser dan search engine. Tujuan dari materi ini agar masyarakat dapat melakukan pencarian informasi yang dibutuhkan melalui koneksi internet yang telah tersedia di rumah pintar.

2) Efektivitas penggunaan search engine. Tujuan dari materi ini adalah masyarakan dapat melakukan pencarian secara efektif dengan memberikan kiat-kiatnya.

3) Pengenalan aplikasi untuk pembuatan konten website. Tujuan dari materi ini agar masyarakat dapat mengetahui ragam aplikasi yang dapat digunakan untuk membuat konten dari website, sehingga dapat memilih aplikasi yang sesuai dengan kebutuhannya.

4) Pembuatan konten website. Tujuan dari materi ini agar masyarakat dapat membuat konten website yang sesuai dengan kebutuhan informasi yang ingin disampaikan melalui website yang mereka miliki.

5) Pengelolaan website. Tujuan dari materi ini agar masyarakat dapat mengelola website yang telah mereka miliki secara optimal, sehingga dapat digunakan untuk menginformasian potensi daerahnya ke daerah lainnya.

b. Tingkat kesiapan masyarakat untuk memanfaatkan rumah pintar yang diukur dengan menggunakan kuesioner yang diisi oleh para peserta pelatihan. Penguurannya menggunakan pendekatan 4 level evaluasi kerangka kerja, yang indikator-indikatornya meliputi: (Dessler, 2008)

1) Reaksi

2) Pembelajaran

3) Perilaku Kerja

4) Hasil 
2. Dokumentasi

Terdapat beberapa dokumen yang digunakan untuk pengumpulan dan analisa data dalam pelatihan ini adalah sebagai berikut:

a. Berita Acara Kegiatan

Berita acara kegiatan merupakan dokumen yang digunakan untuk merekam hasil observasi yang dilakukan oleh fasilitator terhadap hasil pelatihan yang telah dilakukan. Hasil observasi tersebut akan digunakan untuk tahap evaluasi dari kegiatan pelatihan. Cakupan informasi dari berita acara tersebut dapat dilihat pada gambar 2.

\section{Gambar 2 Berita Acara Kegiatan}

b. Kuesioner

Kuesioner merupakan dokumen yang digunakan untuk merekam timbal balik dari peserta pelatihan, ketika pelatihan

\section{Berita Acara}

Pada hari ini Jumat, tanggal 5 Mei 2017, pukul 13.00 sampai dengan pukul 15.00 telah dilaksanakan kegiatan PPM dalam bentuk pelatihan Peningkatan Potensi. PKK melalui Rumah Pintar di Desa Warga Saluyu, Kecamatan Gunung Halu, Kabupaten Bandung Barat, dengan rincian sebagai berikut:

Pertemuan ke- : 2

Agenda : Penyampaian Modul 1

Materi : Pengenalan website, web browser, dan search engine

Tempat : Balai Desa Warga Saluyu

Peserta : (terlampir)

Catatan Kegiatan:

Mengetahui,

Kepala Desa Warga Saluyu, Nara Sumber

NIP. $\quad \overline{\text { NIPY. }}$

telah selesai diselenggarkana. Cakupan pertanyaan dari kuesioner tersebut dapat dilihat pada tabel 1 . 
Tabel 1 Kuesioner Akhir Pelatihan

\begin{tabular}{|c|c|c|c|}
\hline \multirow[t]{2}{*}{ No. } & \multirow[t]{2}{*}{ Pertanyaan } & \multicolumn{2}{|c|}{ Jawaban } \\
\hline & & TS & \begin{tabular}{c|l} 
S & SS
\end{tabular} \\
\hline \multicolumn{4}{|c|}{ Reaksi } \\
\hline 1. & $\begin{array}{l}\text { Apakah modul pelatihan yang diberikan mudah dipelajari secara } \\
\text { mandiri? }\end{array}$ & & \\
\hline 2. & Apakah penjelasan fasilitator mudah dipahami? & & \\
\hline 3. & Apa fasilitator memberikan kesempatan untuk bertanya? & & \\
\hline 4. & Apakah kegiatan pelatihan bermanfaat untuk anda? & & \\
\hline \multicolumn{4}{|c|}{ Pembelajaran } \\
\hline 1. & Apakah sekarang anda sudah mengetahui fungsi internet? & & \\
\hline 2. & $\begin{array}{l}\text { Apakah sekarang anda sudah tau cara melakukan pencarian } \\
\text { informasi atau } \\
\text { pengetahuan lainnya melalui rumah pintar? }\end{array}$ & & \\
\hline 3. & Apakah anda sudah dapat membuat konten website secara mandiri? & & \\
\hline 4. & $\begin{array}{l}\text { Apakah anda sudah mengetahui bagaimana cara menyimpan } \\
\text { informasi atau } \\
\text { konten ke dalam website? }\end{array}$ & & \\
\hline \multicolumn{4}{|c|}{ Perilaku Kerja } \\
\hline 1. & $\begin{array}{l}\text { Apakah pelatihan ini memotivasi anda untuk memanfaatkan } \\
\text { fasilitas yang ada di rumah pintar? }\end{array}$ & & \\
\hline 2. & $\begin{array}{l}\text { Apakah anda berminat mengubah informasi yang selama ini anda } \\
\text { lakukan secara konvensional menjadi bentuk digital yang lebih } \\
\text { mudah } \\
\text { diinformasikan? }\end{array}$ & & \\
\hline 3. & $\begin{array}{l}\text { Setelah anda mencari informasi seputar pekerjaan anda, apakah } \\
\text { anda sudah } \\
\text { memiliki keinginan untuk meningkatkan kualitas produk anda? }\end{array}$ & & \\
\hline \multicolumn{4}{|c|}{ Hasil } \\
\hline & $\begin{array}{l}\text { Apakah setelah mengikuti pelatihan ini anda merasa pekerjaan anda } \\
\text { terbantu? }\end{array}$ & & \\
\hline 2. & $\begin{array}{l}\text { Apakah materi-materi pelatihan yang diberikan dapat membantu } \\
\text { anda } \\
\text { membuat produk anda menjadi lebih baik? }\end{array}$ & & \\
\hline 3. & $\begin{array}{l}\text { Apakah setelah mengikuti kegiatan ini anda jadi mengetahui } \\
\text { bagaimana } \\
\text { cara memanfaatkan rumah pintar untuk membantu pekerjaan anda? }\end{array}$ & & \\
\hline
\end{tabular}

Keterangan:

$\begin{array}{ll}\text { TS } & \text { : Tidak Setuju } \\ \text { S } & \text { : Setuju } \\ \text { SS } & \text { : Sangat Setuju }\end{array}$

3. Keunggulan dan Kelemahan Luaran atau Fokus Utama Kegiatan

Modul yang dihasilkan telah sesuai dengan kebutuhan masyarakat karena diawali dengan tahap identifikasi kebutuhan dengan cara melakukan wawancara dengan peserta pelatihan. Begitu juga dengan pengukuran tingkat kesiapan masyarakat untuk memanfaatkan rumah pintar sudah valid karena menggunakan indikator-indikator pengukuran dari referensi yang sudah terbukti akurat dalam melakukan pengukuran.

4. Tingkat Kesulitan Pelaksanaan Kegiatan

Penggunaan metode pelatihan yang berdasarkan pada referensi yang digunakan, menyebabkan pelaksanaan kegiatan relatif lebih mudah dilakukan, karena sudah terencana dengan baik. Kompleksitas pelaksanaan kegiatan mulai muncul karena tingkat pemahaman peserta yang beragam dan penggunaan istilah yang belum lazim mereka gunakan, serta penggunaan perangkat pelatihan yaitu tablet karena peserta pada umumnya belum pernah menggunakan.

\section{PEMBAHASAN}

Hasil kuesioner akhir yang diisi oleh 30 peserta pelatihan dapat dilihat pada gambar 3. Terdapat beberapa temuan 
dari pelaksanaan pelatihan, terkait dengan kesiapan masyarakat untuk memanfaatkan rumah pinter tersebut. Hasil temuan tersebut akan dibahas sesuai dengan indikator-indikator yang digunakan sebagai berikut:

1. Reaksi

Berdasarkan hasil kuesioner akhir hanya $90 \%$ peserta pelatihan memberikan tanggapan positif terhadap cara penyajian materi baik dalam bentuk modul maupun dalam bentuk penjelasan secara langsung oleh fasilitator, tetapi baru $50 \%$ peserta yang memberikan tanggapan sangat baik.

Terdapat $10 \%$ yang memberikan tanggapan negatif terhadap cara penyajian materi, angka ketidakpuasan cara penyajian materi dalam bentuk modul lebih tinggi jika dibandingkan dengan cara penyampaian materi oleh fasilitator.

Perbaikan pembuatan modul perlu dilakukan agar para peserta pelatihan dapat belajar secara mandiri dan modul tersebut juga dapat digunakan sebagai referensi untuk masyarakat lainnya yang belum mengikuti pelatihan tersebut.

2. Pembelajaran

Sebanyak $93 \%$ peserta pelatihan memberikan tanggapan positif terhadap proses pembelajaran dalam pelaksanaan pelatihan, 25 dari 30 peserta menyatakan sudah sangat mengetahui bagaimana cara untuk mencari informasi dengan menggunakan search engine, bahkan tidak ada satu orang pun yang menyatakan tidak tahu cara pencarian informasi tersebut.

Sedangkan untuk fungsi dari internet 2 orang menyatakan tidak mengetahui, untuk pembuatan konten website dan pengelolaan website 3 orang menyatakan tidak tahu, berarti hanya sebagian kecil saja dari peserta yang belum bisa memahami materi yang disampaikan dengan baik.

Pembuatan konten website dan pengelolaan website hanya 5 dari 30 peserta yang menyatakan sudah sangat paham, sehingga masih diperlukan pelatihan lanjutan untuk materi-materi tersebut, karena memang diperlukan waktu yang relatif lebih lama untuk bisa membuat konten website dan pengelolaan website dengan baik, karena perlu banyak praktek dan yang paling sulit adalah pencarian ide dari konten tersebut.

3. Perilaku Kerja

Sebanyak $97 \%$ peserta memberikan tanggapan positif terhadap materi pelatihan yang dapat merubah perilaku masyarakat dalam memanfaatkan rumah pintar untuk membantu pekerjaannya sehari-hari. Hal ini juga membuktikan bahwa materi yang diberikan sudah sesuai dengan kebutuhan masyarakat, karena tujuan dari pelatihannya sudah bisa dicapai yaitu masyarakat sudah dapat merubah pola perolehan informasi yang awalnya dilakukan secara konvensional sekarang mereka peroleh dengan memanfaatkan rumah pintar.

Motivasi dan keinginan untuk memperbaiki kualitas pekerjaannya setelah mengikuti pelatihan sudah sangat baik, hampir 25 dari 30 peserta menyatakan sangat termotivasi dan berkeinginan untuk memperbaiki hasil pekerjaan dengan cara memanfaatkan rumah pintar. Tetapi masih ada juga yang belum termotivasi meskipun jumlahnya sangat sedikit, tapi tetap perlu dicari cara untuk memotivasi mereka. Karena tanpa motivasi akan sangat kecil kemungkinan mereka untuk memanfaatkan rumah pintar.

Sedangkan keinginan untuk merubah cara penyampaian informasi kedalam bentuk digital hanya 7 orang saja yang antusias untuk melakukannya, ini berbanding lurus dengan cukup sedikitnya peserta yang sudah mampu membuat konten dan pengelolaan website dengan baik.

4. Hasil

Terdapat 93\% peserta yang memberikan tanggapan positif terhadap hasil dari pelatihan yang telah mereka ikuti. 27 dari 30 peserta menyatakan sudah mengetahui bagaimana cara untuk memanfaatkan rumah pintar, terutama untuk kepentingan pekerjaan mereka sehari-hari, dan tidak ada satu pun yang menyatakan tidak mengetahuinya.

Hanya 7 dari 30 peserta yang menyatakan bahwa pelatihan telah sangat membantu pekerjaan mereka sehari-hari, sehingga memang masih diperlukan pendampingan terhadap masyarakat untuk secara konsisten memanfaatkan rumah pintar untuk membantu dan meningkatkan kualitas pekerjaannya sehari-hari.

Meskipun $93 \%$ peserta menyatakan bahwa pelatihan yang diselenggarakan sudah cukup membantu mereka untuk dapat memanpaatkan rumah pintar secara optimal, sehingga diharapkan dapat mengurangi kesenjangan digital yang masih terjadi di Indonesia. 


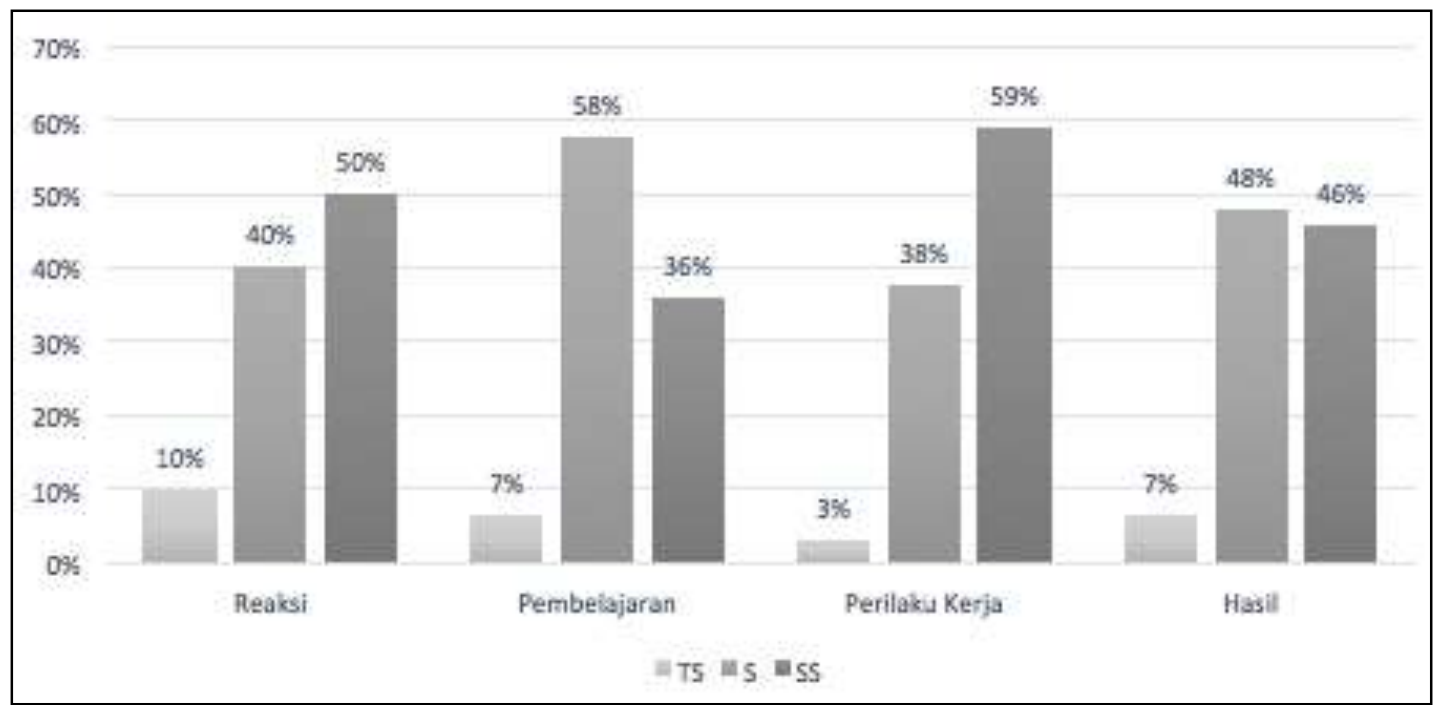

Gambar 3 Hasil Kuesioner Akhir

\section{SIMPULAN DAN SARAN}

1. Berdasarkan indikator-indikator yang digunakan untuk mengukur tingkat kesiapan masyarakat dalam memanfaatkan rumah pintar sudah dapat disimpulkan tujuan pelatihannya tercapai, karena diatas $90 \%$ peserta memberikan tanggapan yang positif.

2. Indikator perilaku kerja menunjukkan persentase yang paling besar pada tingkat sangat memuaskan, hal ini menunjukkan bahwa pelatihan yang diselenggarakan sudah tepat dan sesuai dengan kebutuhan pelatihan.

3. Pelatihan yang diselenggarakan memberikan dampak positif, karena $90 \%$ lebih peserta sudah mengetahui dan merasa termotivasi untuk memanfatkan rumah pintar untuk membantu dan meningkatkan kualitas pekerjaan mereka seharihari.

4. Perlu dibuat lagi pelatihan lanjutan untuk menjaga konsistensi dan lebih mengoptimalkan lagi pemanfaatan rumah pintar.

\section{DAFTAR PUSTAKA}

1. Icmi, Ajeng Apriliana Nur, (2015). Penyelenggaraan Program Pendidikan dan Pelatihan Pemantapan Pendamping Kelompok Usaha Bersama (KUBE) di Balai Besar Pendidikan dan Pelatihan Kesejahteraan Sosial Yogyakarta, Skripsi, Program Sarjana Universitas Negeri Yogyakarta, Yogyakarta.

2. Schuler, Randal S. \& Huber, Vandra L. (1993). Personnel and Human Resource Management, edisi kelima, New York: West Publishing Company, hal. 511-520.

3. Dessler, Gary. (2008). Human Resource Management, edisi sebelas, Pearson Prentice Hall. 
7. FOTO KEGIATAN

1. Pembukaan Kegiatan Pelatihan oleh Kepala Desa
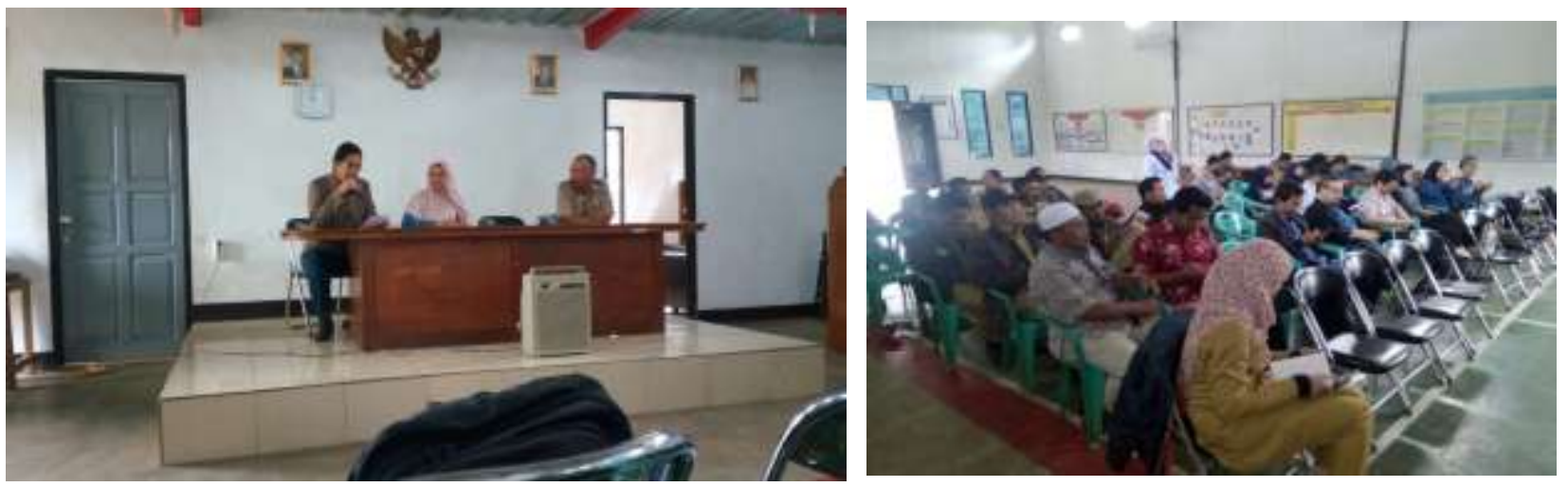

2. Perangkat dan Tempat Pelatihan
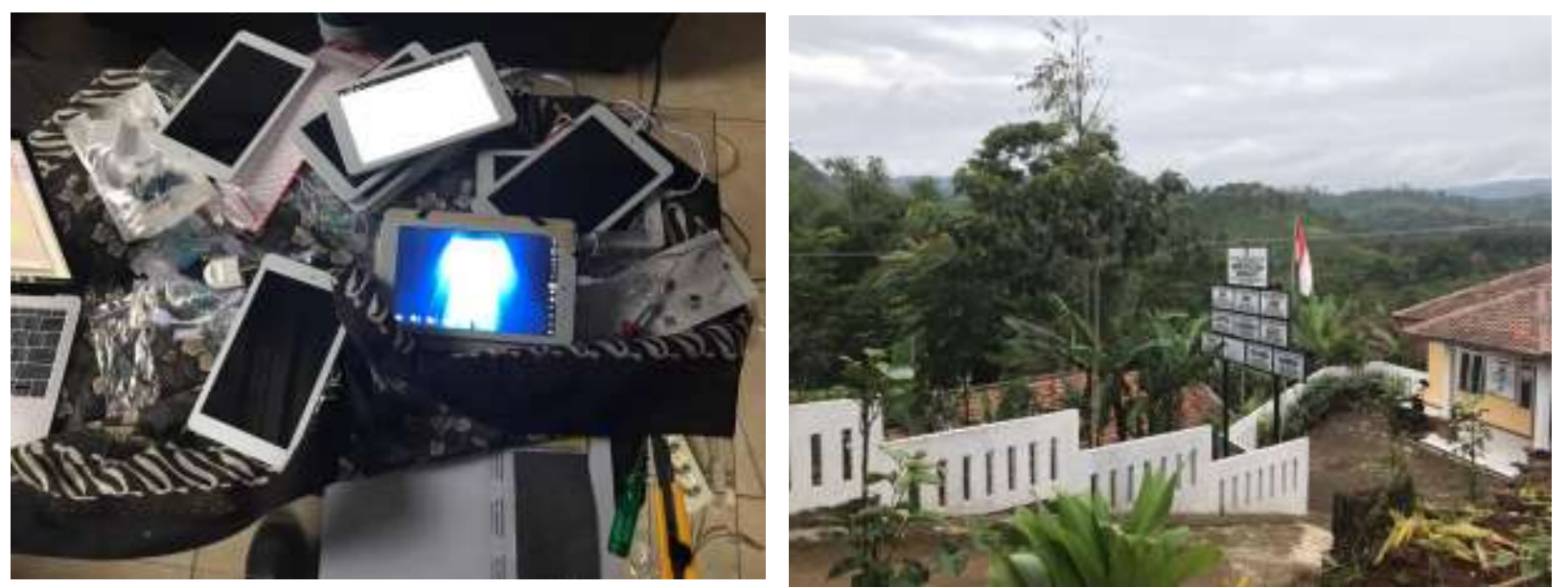

3. Pelatihan untuk Para Petani dan UMKM
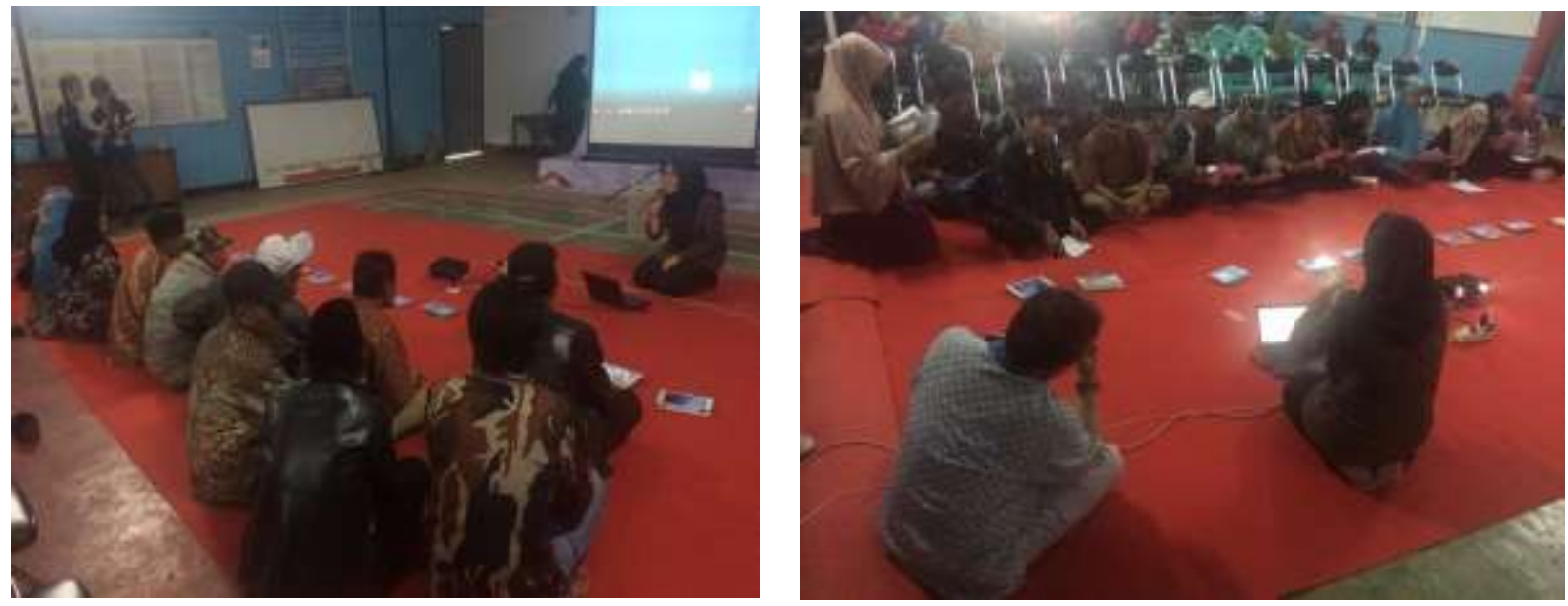
4. Pelatihan untuk Ibu-ibu PKK
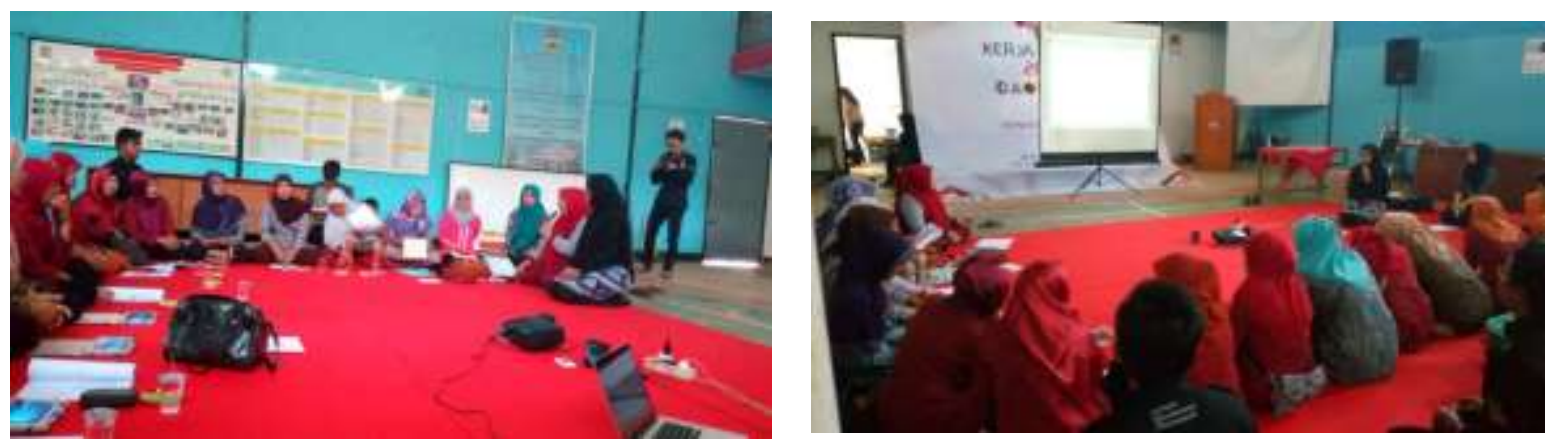

5. Pelatihan untuk Para Guru dan Anak-anak Sekolah
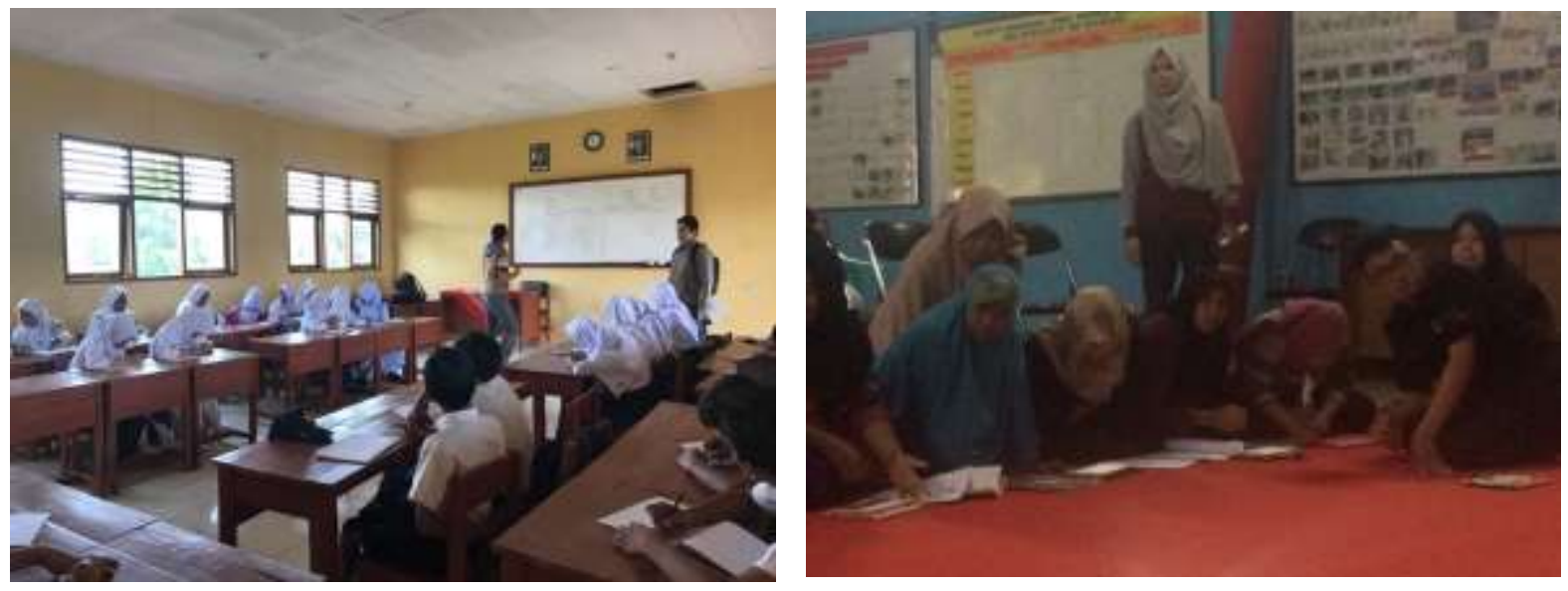

\section{IDENTITAS PENULIS (BIODATA BERUPA NARASI SINGKAT)}

Penulis 1 adalah Mellia Liyanthy, S.T, M.T merupakan staf pengajar di Program Studi Teknik Informatika Universitas Pasundan Bandung, dengan bidang kepakaran Multimedia.

Penulis 2 adalah Anggoro Ari Nurcahyo, S.T, M.Kom merupakan staf pengajar di Program Studi Teknik Informatika Universitas Pasundan Bandung, dengan bidang kepakaran Sistem Informasi.

Penulis 3 adalah R. Djunaedy Sakam, S.T, MT merupakan staf pengajar di Program Studi Teknik Informatika Universitas Pasundan Bandung, dengan bidang kepakaran Sistem Informasi. 